\title{
Some studies on ethnic minorities in Vietnam
}

\author{
Nguyen Thi Linh
}

AISDL

$28-5-2021$

Although the Party and State have issued and implemented many policies to develop all aspects of life and society of ethnic minorities. However, due to various reasons, both subjective and objective, the life of the ethnic minorities in our country in general still faces many difficulties, the population level is low.

The following articles [1-3] seeks to complement earlier studies on ethnic minority underdevelopment in Vietnam. All articles are used data from the Vietnam Household Living Standards Survey (VHLSS).

The paper "Ethnic wage inequality in Vietnam" [1] is the first to analyze the ethnic wage gap between the Kinh (and Chinese) and other ethnic minority groups in the Vietnam labor market and one of the few to examine pay differentials between this majority and minority groups. The results confirm the existence of an ethnic wage gap in the labor market, even magnitude of the ethnic wage gap for this employment category could be wider because $72 \%$ self-employed operating in either agriculture or non-farm activities. And the ethnic wage gap is largely attributable to differentials in the returns to endowments, given negligible differences in selection effects between the two groups.

Following the studies on ethnic minorities, two articles, "Ethnic Minorities in Northern Mountains of Vietnam: Employment, Poverty and Income" [2] and "Factors affecting the intensity of nonfarm participation among ethnic minorities in , Vietnam" [3], are more indepth research articles on ethnic minorities in Northern Vietnam. Generally, the ethnic minorities in Northern Mountains have much lower assets and income than Kinh/Hoa (ethnic majorities) and ethnic minorities in other regions with income is mainly from agricultural activities, especially crops and livestockcrops and livestock. If the income poverty line in 2010 of 400 thousand VND per person per month, the poverty rate of ethnic minorities in this survey is $67.3 \%$. Meanwhile, the poverty rate of ethnic minorities in other regions is $34.9 \%$ and the whole country is $9.9 \%$.

Nonfarm employment helps this households in Northwest Mountains had much higher levels of education, income, assets, and a much lower level of poverty than those without its. However, their access and time for to nonfarm employment is limited and low. Therefore, 
it is necessary to focus on promulgating appropriate policies and schemes, especially allocating investment resources to support socio-economic development in ethnic minority areas, ensuring harmonious development among regions, domain in the same locality.

\section{Note}

This preprint is supplementary document for the research project "The rise of research on development economics in Vietnam SSHPA 2008-2020 dataset" [4]. Employing the Mindsponge though process $[5,6]$, the research project aims to provide a comprehensive review of development economics field in Vietnam from 2008 until 2020.

The openness of this preprint is a support for open science. We proactively endorse the concept of reusability of open data $[7,8]$. We believe the practice will help to prevent our study from potential shortcomings [9], and to inform socio-economic studies and policies at lower costs [10].

\section{References}

[1] Pham, H. and Reilly, B. (2009). Ethnic wage inequality in Vietnam. International Journal of Manpower, 30(3), 192-219.

[2] Nguyen, C., Tran, T. and Van Vu, H. (2016). Ethnic Minorities in Northern Mountains of Vietnam: Employment, Poverty and Income. Social Indicators Research, 134(1), 93115.

[3] Tran, T., Vu, H. and Doan, T. (2016). Factors affecting the intensity of nonfarm participation among ethnic minorities in Northwest Mountains, Vietnam. International Journal of Social Economics, 43(4), 417-430.

[4] Ho, M. T. (2020). The rise of research on development economics in Vietnam SSHPA 2008-2020 dataset [Dataset]. Open Science Framework. Retrieved from https://osf.io/32q89/; DOI: 10.17605/OSF.IO/32Q89.

[5] Vuong, Q. H., \& Napier, N. K. (2015). Acculturation and global mindsponge: an emerging market perspective. International Journal of Intercultural Relations, 49, 354-367.

[6] Vuong, Q. H. (2016). Global mindset as the integration of emerging socio-cultural values through mindsponge processes: A transition economy perspective. In J. Kuada (ed.) Global Mindsets: Exploration and Perspectives (pp. 109-126). London: Routledge.

[7] Vuong, Q. H. (2017). Open data, open review and open dialogue in making social sciences plausible. Nature: Scientific Data Updates. URL: <http://blogs.nature.com/scientificdata/2017/12/12/authors-corner-open-dataopen-review-and-open-dialogue-in-making-social-sciences-plausible/>. 
[8] Vuong QH. (2019). Breaking barriers in publishing demands a proactive attitude. Nature Human Behaviour, 3(10), 1034, DOI: 10.1038/s41562-019-0667-6.

[9] Vuong, Q. H. (2018). The (ir)rational consideration of the cost of science in transition economies. Nature Human Behaviour, 2(1), 5, DOI: 10.1038/s41562-017-0281-4.

[10] Vuong, Q. H. (2020). Reform retractions to make them more transparent. Nature, 582(7811), 149, DOI:10.1038/d41586-020-01694-x 